\title{
ОСНОВНЫЕ ТЕНДЕНЦИИ МНОГОСТОРОННЕГО ПАРТНЁРСТВА РОССИИ И ИРАНА В РАМКАХ ЕАЭС"
}

\author{
(c) 2020 Шнайдер Виктор Викторович \\ кандидат экономических наук, доцент департамента бизнес-аналитики \\ Финансовый университет при Правительстве РФ, Россия, Москва \\ E-mail:VVShnajder@fa.ru
}

Основные тенденции многостороннего партнёрства России и Ирана в рамках ЕАЭС стремительно переформатируются в мировом сообществе в направлении политической многополярности и перехода к формированию крупных региональных экономических партнерств.

В условиях распространения практики протекционизма политика национальных государств достаточно прагматична. Данная тенденция более широко распространена в американской и западной европейской политике. Однако, в этой ситуации, хотя и временно возникающие, несправедливые условия конкурирования иностранных компаний на рынках стран ЕАЭС могут сопутствовать утрате национальных рабочих мест, повышению уровня безработицы и обострению социальных проблем.

С другой стороны, сохраняющиеся барьеры и ограничения мешают развитию всего евразийского пространства, что прекрасно понимают его участники. Более того, это порождает и такое явление, как контрабанда, чего на свободном рынке товаров не может быть по определению.

В свою очередь создание Таможенного союза позволило государствам-участницам, сформировать единую таможенную территорию, ликвидировать таможенный контроль в рамках внутренних границ, что значительно увеличило объемы экспорта и импорта различных товаров и повлияло на интеграцию рабочей силы.

Развитие ЕАЭС как интеграционного образования формирует предпосылки вступления в ряды союза других государств, в т.ч. в первую очередь пост советского пространства. Но принятие новых членов сопряжено с рядом формализованных процедур, и в первую очередь исключающих для «старых членов» подорожания импортируемых товаров, связанных с ощутимой разницей между таможенными тарифами ЕАЭС и тарифами новых членов, при этом эксперты указывают, что вступление новых стран в союз принесет гораздо больше пользы, чем негатива.

Евразийский экономический союз значительно повлиял на рост покупательной способности стран-участниц, усилил рост ВВП, что в свою очередь отразилось на росте оборотов внутренней и внешней торговли. Положительное влияние создания Евразийского экономического союза не осталось без внимания мировым экономическим сообществом, и, соответственно, побудило интерес к ЕАЭС со стороны многих государств.

Несомненно, интенсивный путь развития ЕАЭС, предполагает закрепление связей и развитие взаимовыгодных взаимоотношений внутри Союза, способствующих укреплению конкурентоспособности евразийского объединения в мировой экономике.

Ключевые слова: анализ, мировое сообщество, партнерство, приоритетные направления, реформирование, свободная торговля, тенденции, экономика.

Многостороннее партнерство России и Ирана в рамках ЕАЭС имеет двусторонний диалог, нацеленный на долгосрочный период. 2015 год для стран ознаменован подписанием совместного всеобъемлющего плана действий относительно ядерной программы Ирана [4].

«Российско-иранские отношения на протя- жении последних десятилетий прошли серьезное испытание чередой стремительных взлетов и столь же неожиданных падений» [5].

17 мая 2018 года Ираном в рамках Евразийского экономического союза подписано временное соглашение о зоне свободной торговли, позволяющее определить приоритетные на-

\footnotetext{
* Статья подготовлена по результатам исследований, выполненных за счёт бюджетных средств по государственному заданию Финансовому университету
} 
правления и подходы к торгово-экономическим отношениям на основе многостороннего партнерства.

«Поиск фундаментальной основы для стратегического партнерства требует системной ревизии двусторонних отношений: того, что уже реализовано или реализуется, и тех потенциальных возможностей, которые открываются в условиях меняющейся экономической, региональной и глобальной ситуации» $[4$, с. 4].

Россией и Ираном определены пути снижения спорных вопросов взаимоотношений и устранения различных препятствий, снижающих эффективность двустороннего сотрудничества.

Проект «Российско-иранские отношения на современном этапе» закрепляет многостороннее партнерство между странами-участницами [4]. С 2014 года Российский совет по международным делам (РСМД) используя проект, формирует ряд перспективных мероприятий (см. рисунок 1).

«Российско-иранский политический диалог основан на совпадении или близости позиций двух стран по большинству вопросов мировой и региональной повестки» [2].

Выше обозначенный период ознаменован подписанием соглашение о долгосрочном исследовательском сотрудничестве и подготовкой предложений по многостороннего российскоиранского партнерства. С 2016 года проводится совместная работа экспертов РСМД и IRAS в особо значимых направлениях (см. рисунок 2).

Примечательно и то, что российско-иран- ские эксперты имеют единое мнение в части стратегического партнерства, нуждающегося в развитии динамичной основы и реальном наполнении научной составляющей, экономике, транспорте, торговли и т.д. Многостороннее партнерство между странами способствует формированию зоны свободной торговли, которая осуществляется с 2019 года. «За январь-август 2019 года поставки из ЕАЭС в Иран выросли более, чем на $17 \%$, а товарооборот за этот период превысил 2 млрд. долл. США» [3].

ЕАЭС для Россия и Иран открывает перспективы многостороннего партнёрства и направления взаимовыгодного развития. Пристальное внимание внутри ЕАЭС уделяется разработке действенной и продуктивной промышленной политики. Важным шагом в этом направлении явилось создание в мае 2019 г. совета по промышленной политике стран ЕАЭС. Ключевые функции и задачи совета по промышленной политике ЕАЭС представлены на рисунке 3.

«Экономические интересы России и государств-участников ЕАЭС определяются оценкой перспектив их многосторонней кооперации» [1, с. 131].

В заключении отметим, что, несмотря на то, что в российско-иранских взаимоотношения многосложны, основными направлениями взаимовыгодного промышленного сотрудничества признаны цифровые отрасли экономики, инновационные направления экономики, промышленная кооперация, взаимная торговля и развитие механизмов экспорта продукции, инвестиционные проекты.

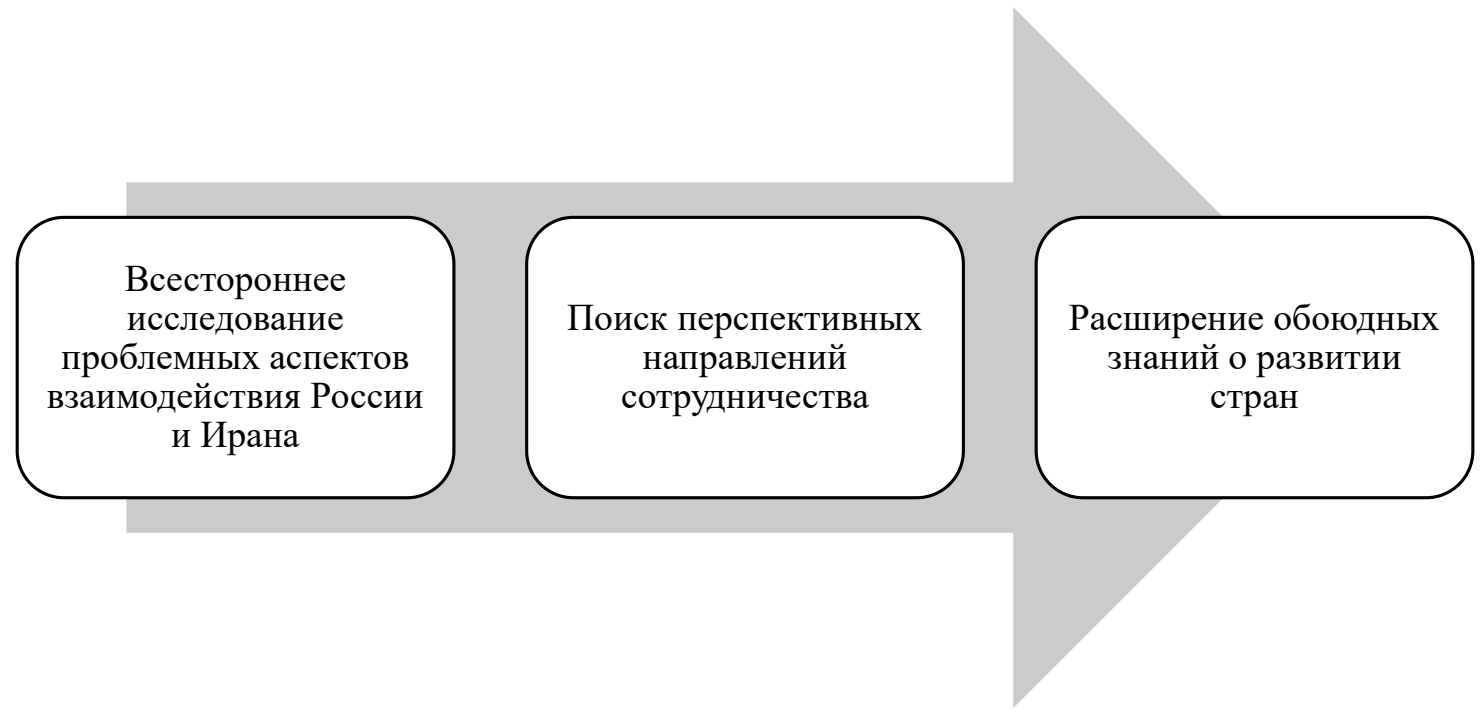

Рисунок 1. Мероприятия многостороннего российско-иранское партнерства Источник: составлено авторами 


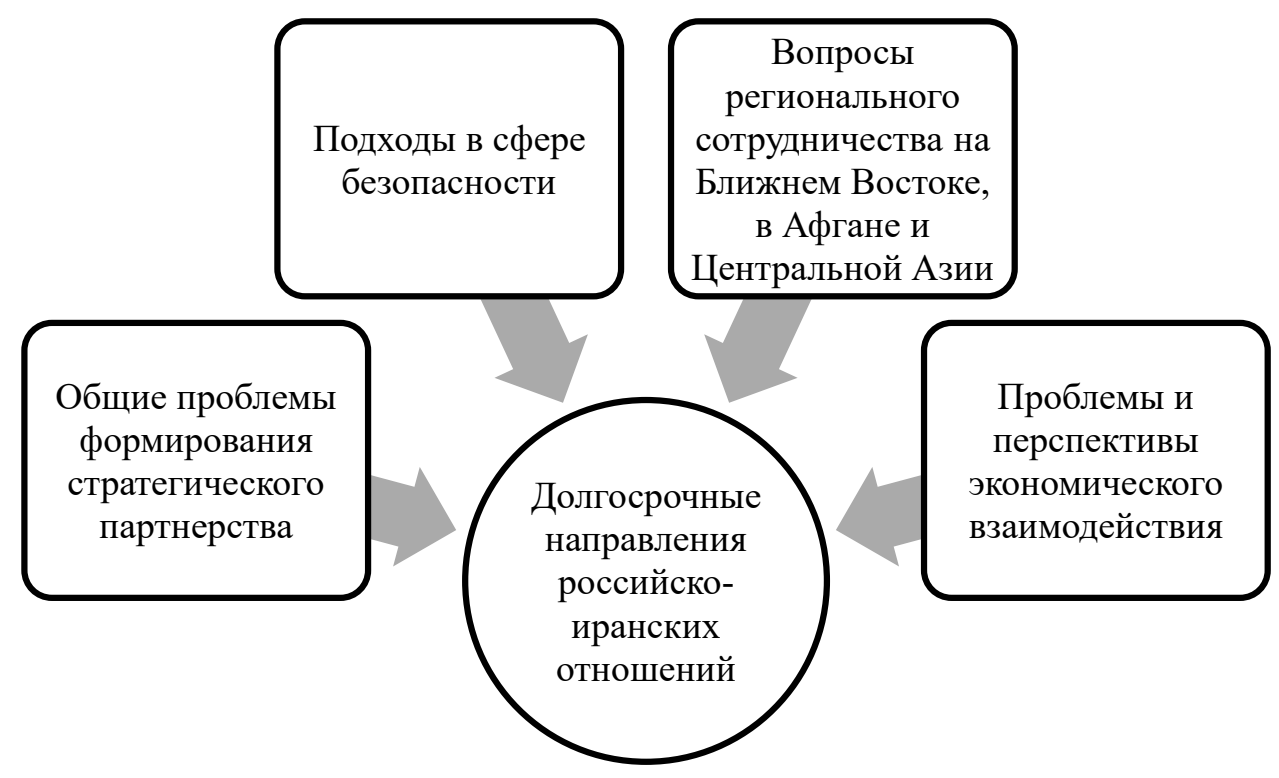

Рисунок 2. Направления многостороннего российско-иранского партнерства Источник: составлено авторами

Взаимодействие сторон по вопросам создания производств конкурентоспособной продукции на основе новых цепочек добавленной стоимости
Выработка предложений по вопросам углубления взаимодействия государствчленов при реализации промышленной политики в рамках союза

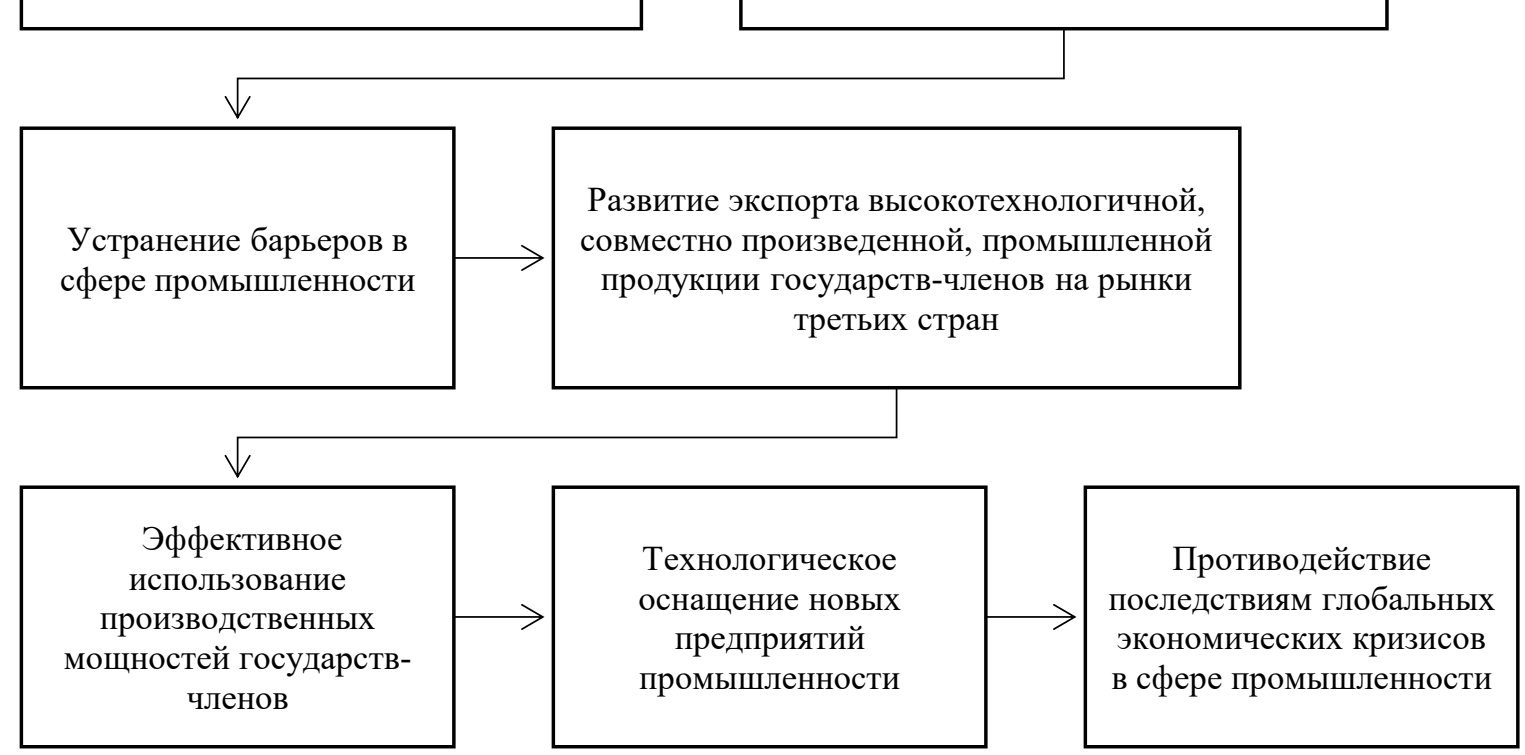

Рисунок 3. Функции совета по промышленной политике ЕАЭС Источник: составлено авторами 


\section{Библиографический список}

1. Абрамов В.Л., Абрамова О.Д. Экономические интересы России и ЕАЭС в интеграционном взаимодействии с ключевыми странами АТР при формировании Большого Евразийского Партнерства // PolitBook - 2018-3. https://cyberleninka.ru/article/n/ekonomicheskie-interesy-rossii-i-eaes-v-integratsionnom-vzaimodeystvii-sklyuchevymi-stranami-atr-pri-formirovanii-bolshogo.

2. ВАХШИТЕХ Ахмад Насер - аспирант кафедры сравнительной политологии факультета гумани-тарных и социальных наук Российского университета дружбы народов (117198, Россия, г. Москва, ул. МиклухоМаклая, 5; ahmadvakhshiteh@gmail.com)

3. ЕАЭС и Иран переходят на преференциальные условия торговли/ 28.10.2019 http://www.eurasiancommission. org/ru/nae/news/Pages/28-10-2019-1.aspx

4. Партнерство России и Ирана: текущее состояние и перспективы развития. Доклад № 29/2017 / [Б. Амирахмалиан, Х. Азизи, С. В. Демиденко, Е. В. Дунаева, В. В. Евсеев, П. В. Зюзин, И. С. Иванов, Дж. Карами, А. В. Кортунов, Д.Киани, А.А.Князев, Н.А.Кожанов, Г.В.Лукьянов, Н. М. Мамедов, Р. Мусави, Ф.Паранд, М.К.Саджадпур, Ж. Шакиби, М. Санаи, М. Шариатиниа, М. Шури, В. И. Сажин, М. Тишейар, П. В. Топычканов]; [гл. ред. И. С. Иванов]; Российский совет по международным делам (РСМД).- М.: НП РСМД, 2017.-184 с.

5. Филин Н.А. и др. Вестник РУДН. Серия: Международные отношения. 2016. Т. 16. № 4. С. 677-687 